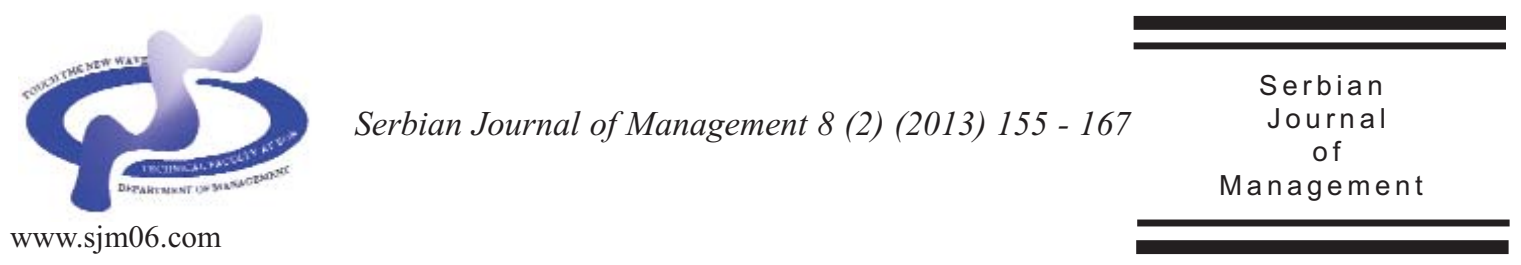

\title{
HUMAN RESOURCE MANAGEMENT BEST PRACTICES AND FIRM PERFORMANCE: A UNIVERSALISTIC PERSPECTIVE APPROACH
}

\author{
Loo-See Beh ${ }^{a^{*}}$ and Leap-Han Loo ${ }^{a}$

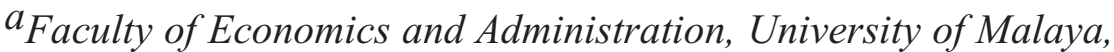 \\ 50603 Kuala Lumpur, Malaysia
}

(Received 15 May 2013; accepted 8 October 2013)

\begin{abstract}
The universalistic perspective of human resource management practices perceives that a set of practices can achieve competitive advantage and firm performance. This study sought to investigate the relationship between best human resource practices and firm performance. A descriptive survey research design was used to gather primary data using self-administered questionnaire. The study population $(n=312)$ was comprised of non-executives, executives, managers, and top management from seven major insurance firms at headquarters in the Klang Valley, Malaysia. The study found that performance appraisal, internal communication, SHRM alignment in the organization, and career planning were the human resource management best practices.
\end{abstract}

Keywords: Human Resource Management Practices, Competitive Advantage, Firm Performance, Insurance Firm.

\section{INTRODUCTION}

The perceived level of productivity and customer service provided by the insurance industry in Malaysia has deteriorated due to lack of skilled and competent workforce. Organization today, specifically insurance industry is aware of the importance of human resource management (HRM) as the leading indicator in achieving improved sales growth and the creation of innovative insurance products. Therefore, local insurance firms have to be more efficient, productive and innovative on its HRM practices implementation that is closely aligned to the firm's objective, business needs as well as the culture to sustain competitive advantage in the market. The contribution of this paper

* Corresponding author: lucybeh@um.edu.my

DOI:10.5937/sjm8-4573 
to the literature is twofold. First, the conceptual model of the study tested the relationship between HRM best practices and firm performance at the organizational level. The second contribution is to demonstrate the impact of the strength of the HRM best practices on firm performance.

\section{BACKGROUND OF THE STUDY}

The impact of globalisation, market force and highly competitive markets has forced the insurance industry to be competitive (Kundu \& Malhan, 2009) in order to sustain in the market, locally and internationally. A high level of skilled and competent workforce can contribute to the firm's success by developing a comprehensive and internally cohesive human resource management (HRM) system that is embedded in the organization's structure and culture (Liu et al., 2007). A synergistic HRM system is a pathway through which the firm's human capital has the potential to become an important source of competitive advantage and to enhance firm performance (Boxall \& Purcell, 2003) by shifting their focus to making service quality, productivity, product innovation and sales growth a priority in gaining competitive advantage.

Strategic HRM practices generally focus on human resource strategy, integration and add to the key notions of strategies (Armstrong, 2007). Literature review shows that organizations engaging or adopting HRM best practices will outperform organizations that do not. Given the rapid growth and development in the insurance industry, human resources are considered a firm's key internal resource and are increasingly deployed as the source of competitiveness in an organization. A great number of empirical studies show that the best practices of HRM has positive relationship on firm performance and also can be the source of sustainable competitive advantage to the organization (Schuler \& MacMillan, 1984; Ulrich, 1991, Wright \& McMahan, 1992; Huselid, 1995; Jackson \& Schuler, 1995; Bjorkman \& Fan, 2002; Collins \& Clark, 2003; Guest et al., 2003; Panayotopoulou et al., 2003; Wright et al., 2005; Hiltrop, 2005; Gooderham et al., 2006;

Othman, 2009).

\section{LITERATURE REVIEW}

There is little agreement as to which HRM best practices can be considered as strategic in an organization (Paauwe, 2004; Marchington \& Grugulis, 2000). However, there is a broad consensus that there is a positive link between HRM practices and firm performance (Wattanasupachoke, 2009; Tessema \& Soeters, 2006; Wright et al., 2005; Bjorkman \& Fan, 2002; Singh, 2003a; Bae \& Lawler, 2000; Huselid et al., 1997; Harel \& Tzafrir, 1999; Huselid \& Becker, 1996; Huselid, 1995; Arthur, 1992). Huselid's (1995) groundbreaking study established that a set of human resource practices, also known as high performance work systems (HPWS) were strongly related to turnover, accounting profits and firm market value. Since then, many studies have shown similar positive relationship between HRM practices and various measures of firm performance such as productivity and quality in the auto assembly plants (MacDuffie, 1995), accounting profits in the bank sector (Delery \& Doty, 1996), employee productivity, machine efficiency, and customer alignment and its link with quality manufacturing strategy (Youndt et al., 1996), 
and profitability (Guthrie, 2001). The literature review in this study includes only those studies covering multiple HRM practices, because the focus is on the HRM system as a whole that promotes overall firm performance. The review on measurement of organizational outcomes (productivity, quality, and service) and capital market outcome (sales growth) is based on Dyer \& Reeves's (1995) and Delaney \& Huselid's (1996) studies.

Review of literatures indicate that essential HRM practices such as workforce planning (Mathis \& Jackson, 2004; Chang \& Chen, 2002), training and development (Khan, 2010; Katuo \& Budhwar, 2006; Ahmad \& Schroeder, 2003; Kundu, 2003; Chang \& Chen, 2002; Lam \& White, 1998; Ngo et al., 1998), recruitment and selection (Khan, 2010; Katuo \& Budhwar, 2006; Kulik, 2004; Ahmad \& Schroeder, 2003; Chiu et al., 2002; Lam \& White, 1998), performance appraisal (Khan, 2010; Chang \& Chen, 2002; Bernardin \& Russel, 1993), career planning management (Schein, 1996), compensation (Ahmad \& Schroeder, 2003; Chiu et al., 2002; Lam \& White, 1998; Ngo et al., 1998), internal communication (Ulrich, 1997; Richard \& Johnson, 2001; Geringer et al., 2002; Oladipo \& Abdulkadir, 2011; Osman et al., 2011), and job design (Champion, 1988 ; Morgeson \& Humphrey, 2006) have positive association with firm performance. These practices capitalise on the strength of the human capital for sustained competitive advantage (Jackson \& Schuler, 2000). Furthermore, these studies also provide an insight to the management and human resource practitioner to exercise these practices as strategic tool for superior performance (Khan, 2010).

Akhtar et al. (2008) adopted Delery \& Doty's (1996) seven best practices (i.e. training, participation, employment security, job description, result-oriented appraisal, internal career opportunities, and stocks/profit sharing) approach to examine the validity of HRM practices and their effects on company performance among the 465 Chinese enterprises. The findings showed that training, participation, resultoriented appraisal, and internal career opportunities were identified as the "core" of HRM practices that positively affect both product/service performance and financial performance. Akhtar et al.'s, (2008) findings are consistent with the results study done by Shipton et al., (2005). On the other hand, Gooderham et al. (2006) conducted a similar study using a factor analysis of 80 different HRM practices on its relationship with organizational performance among the European firms. The study shows that training monitoring, share-options, evaluation of Human Resource Department, profit-sharing, group-bonus, and performance related pay have a statistically significant impact on performance. Furthermore, Ngo et al.'s (1998) findings indicate that firms that provide more structural training and development create more new products, have more satisfied employees and higher sales. Fey et al. (2000) also finds that non-technical training, high salaries and promotions based on merit will have a direct positive impact on firm performance among the managers while job security among the non-managerial employees.

Universalistic perspective focuses on the 'best practices', which implies that firms will be better off if they identify and adopt 'best practice' in the way they manage people (Boxall \& Purcell, 2000). In other words, some human resource practices are always better than others (Rose \& Kumar, 2006) 
regardless of the firm, its strategy or its environment (Delery \& Doty, 1996) and all organisations should adopt them (Miles \& Snow, 1984). From this perspective, for a firm to have effective human resource practices, it needs to copy and implement these universal best practices. There are many empirical evidences suggesting that human capital is the pre-eminent organisational resource and the main key to achieving superior performance. Therefore, human capital provides organisation with an important source of sustainable competitive advantage (Huselid, 1995).

The universalistic academicians consider strategic HRM practices to positively influence firm performance and help firms improve their human resource cost benefits, improve operating efficiency, increase innovation, and increase overall organisational performance benefits (Dyer \& Reeves, 1995). According to Osterman (1987) and Sonnenfeld \& Peiperl (1988), the most influential best practices set consist of seven practices namely internal career opportunities, training systems, appraisals, profit-sharing plans, employment security, voice mechanisms (grievance systems and participation in decision making) and degree to which jobs are narrowly designed. Many scholars have supported this universalistic prediction (Terpstra \& Rozell, 1993; Delery \& Doty, 1996) and firms desire to succeed in today's global environment and competition must make appropriate human resource investment to acquire and develop human capital who acquire better skills, capabilities, and knowledge than their competitors.

In summary, the above reviews have unified a list of HRM practices needed for HRM best practices research and argued that it is the synergistic effect of multiple HRM practices that contributes to firm's performance. Organization needs to develop a human resource system that achieves both horizontal and vertical integration in achieving competitive advantage. However, there is no consensus or consistency evidence illustrating what constitutes these HRM best practices that associate with high firm performance. While a substantial body of literature has been developed linking HRM best practices to firm performance, this research study applies the universalistic perspective of human resource practices to :

1) Investigate the individual HRM best practices on firm performance in the Malaysian insurance industry.

2) Assess the relationship between HRM best practices and firm performance in the Malaysian insurance industry.

Identifying the important components of HRM best practices for firm performancewill help us better theorize the nature and impact of HRM-performance relationship. Therefore, from the literature review, the conceptual model of this study is presented in Figure 1.

\section{RESEARCH METHODOLOGY}

The descriptive research method is used to facilitate the description of the SHRM and firm performance of seven major insurance firms operating in Klang Valley. The descriptive method provides logical approach because the data consisted of the perceptions of respondents, which were gathered through the administered survey questionnaire. This method of data collection was chosen for this study as it provides greatest anonymity and lowest chance of biasness. The sample was composed of the non-executive, executive and managerial/top management employees of seven major 


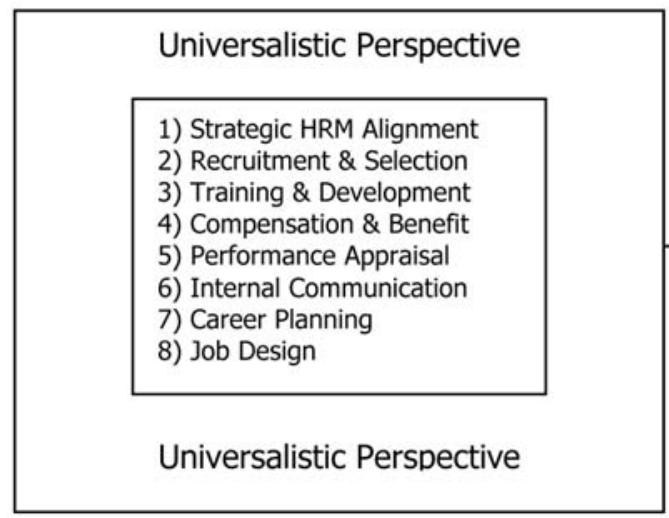

Figure 1. Conceptual model of the study

insurance firms available in Klang Valley. Permission was granted from the Life Insurance Association of Malaysia and General Insurance Association of Malaysia to conduct this survey among its members. A total of 350 questionnaires were distributed to seven different major insurance firms using the method of stratified sampling. The response rate is $89 \%$. For the purpose of this study, the survey questionnaire constitutes three parts. The first part comprises demographic characteristics of the respondents such as gender, name of organization, age, education, year of service, designation and total employees. The second part of the questionnaire consists of 64 items which represent eight HRM best practices and rated anonymously by the respondents on a 5-point Likert scale of $1=$ "strongly disagree" to $5=$ "strongly agree". The third part of the questionnaire measures the firm performance by the following variables namely: 1) rate of productivity of your company, 2) customer service, 3) quality of products, and 4) sales growth developed by Dyer \& Reeves (1995) and Delaney \& Huselid (1996). Respondents were to rate on a 5-point Likert scale of $1=$ "very poor" to 5 = "very good". The overall Cronbach's Alpha score is 0.87 . The collected data were analyzed using the Statistical Package for

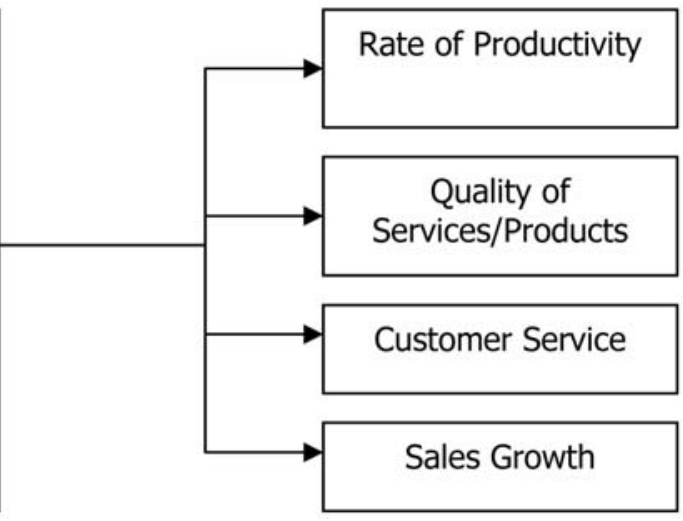

Social Science (SPSS) Version 19. The analysis of data began with the reliability test for the scales using Cronbach's Alpha. This is followed by the examination and presentation of demographic profile of respondents using descriptive statistics. Pearson correlation analysis were carried out to determine the relationships between independent and dependent variables. Multiple regression analysis was used to analyze the level of significance in testing the relationship between HRM best practices and firm performance.

\section{RESULTS}

The results of the demographic characteristics of the respondents show that $57.4 \%$ of the respondents are female while $42.6 \%$ of the respondents are male. This implies that insurance industry in this country gives female preference in the recruitment and selection process. The study also indicates that the majority of the respondents are aged 31 years and above (80.4\%) implying that age is an important factor in appointment of executives, manager and top management. These are responsible positions with high accountability and required a great deal of experience in 
carrying out their duties efficiently and effectively. A total of $64.7 \%$ of respondents obtained Degree and we can presume that overwhelming majority of the respondents were well educated in their area of expertise. $60.3 \%$ of the respondents have been in the industry for at least 5 years of working experience. Majority of the participating insurance firms employ above 200 employees.

Table 1 shows the inter-correlations between measures of HRM best practices whereby the pattern of independent variables are related to the dependent variable by aiming to identify ideal HRM best practices that complement and reinforcing each other. The Pearson's product moment correlation coefficient values reveal strong correlations within the HRM best practice variables as follows: a) Strategic HRM alignment in the organization and internal communication $(\mathrm{r}=0.209, \quad \alpha=0.01), \quad b)$ Strategic HRM alignment in the organization and career planning $(\mathrm{r}=0.311, \alpha=0.01), \mathrm{c})$ recruitment $\&$ selection and training \& development $(\mathrm{r}=0.338, \quad \alpha=0.01), \quad \mathrm{d})$ recruitment $\&$ selection and performance appraisal $(\mathrm{r}=0.190, \alpha=0.01), \mathrm{e})$ recruitment $\&$ selection and internal communication $(\mathrm{r}=0.218$, $\alpha=0.01)$, f) training \& development and compensation $\&$ benefits $(\mathrm{r}=0.382, \alpha=0.01)$, g) training \& development and performance appraisal ( $\mathrm{r}=0.473, \alpha=0.01), \mathrm{h})$ training \& development and internal communication $(\mathrm{r}=0.321, \alpha=0.01), \mathrm{i})$ training \& development and career planning $(\mathrm{r}=0.407, \alpha=0.01), \mathrm{j})$ compensation \& benefits and performance appraisal $\quad(\mathrm{r}=0.220, \quad \alpha=0.01), \quad \mathrm{k})$ compensation \& benefits and career planning $(\mathrm{r}=0.303, \alpha=0.01), 1)$ compensation \& benefits and job design $(r=0.346, \alpha=0.01)$, $\mathrm{m})$ internal communication and career planning ( $r=0.408, \alpha=0.01)$, and $n$ ) career planning and job design $(r=0.469, \alpha=0.01)$.

The findings also show a stronger and positive correlation between performance appraisal practices and firm performance $(r=0.342, \alpha=0.01)$ and followed by internal communication practices $(r=0.285, \alpha=0.01)$, career planning $(\mathrm{r}=0.247, \alpha=0.01)$, and training and development $(\mathrm{r}=0.238, \alpha=0.01)$. This implies that performance appraisal has greatest impact on insurance performance compared with the rest of HRM best practices. Insurance firms view that performance appraisal management is a vehicle for the continuous improvement of business improvement via a co-ordinate program of people management interventions (Walters, 1995). However, the insurance's performance had negative correlation with job design practices.

The multiple regression model with all eight predictors produced $\mathrm{R}^{2}=0.254$,

Table 1. Correlations between HRM best practices and firm performance

\begin{tabular}{|c|c|c|c|c|c|c|c|c|c|}
\hline SHRM Practices & 1 & 2 & 3 & 4 & 5 & 6 & 7 & 8 & 9 \\
\hline 1) Strategic HRM alignment in the organization & 1 & & & & & & & & \\
\hline 2) Recruitment and Selection Practices & .021 & 1 & & & & & & & \\
\hline 3) Training and Development Practices & -.013 & $.338^{11}$ & 1 & & & & & & \\
\hline 4) Compensation and Benefits Practices & .029 & .083 & $.382^{\circ+}$ & 1 & & & & & \\
\hline 5) Performance Appraisal Practices & $-.259^{\circ 10}$ & $.190^{\prime \prime}$ & $.473^{*+1}$ & $.220^{\prime \prime}$ & 1 & & & & \\
\hline 6) Internal Communication Practices & $.209^{\prime \prime}$ & $.218^{\prime \prime}$ & $.321^{\prime \prime}$ & .013 & .051 & 1 & & & \\
\hline 7) Career Planning Practices & $.311^{\circ 0}$ & $.144^{\circ}$ & $.407^{\circ+}$ & $.303^{\prime \prime}$ & $.122^{\circ}$ & $.408^{\circ}$ & 1 & & \\
\hline 8) Job Design Practices & .036 & -.106 & 0.076 & $.346^{\pi 7}$ & -.057 & $.145^{\circ}$ & $.469^{\prime \prime}$ & 1 & \\
\hline 9) Perceived Firm Performance & $.171^{\circ}$ & $.174^{\prime \prime}$ & $.238^{\circ+}$ & .076 & $.342^{\circ}$ & $.285^{\circ}$ & $.247^{\circ "}$ & -.065 & 1 \\
\hline
\end{tabular}


$\mathrm{F}(8303)=12.93, \mathrm{p}<.000 . \mathrm{R}^{2}$ value of 0.254 indicates that $25.4 \%$ of the variance in firm performance is accounted by Strategic HRM alignment in the organization, recruitment and selection, training and development, compensation and benefits, performance appraisal, internal communication, career planning, and job design and its square. $\mathrm{R}$ value of 0.504 indicating a strong relationship between the independent variables (HRM best practices) and dependent variable (firm performance). Findings show that the best predictions of an insurance performance are performance appraisal $(\beta=.376)$, internal communication ( $\beta=.201)$, Strategic HRM alignment in the organization $(\beta=.183)$, and career planning $(\beta=.149)$. These variables explain up to $25.4 \%$ of firm performance with performance appraisal taking the lead.

\section{DISCUSSION AND CONCLUSION}

In this study, we have investigated the relationship of HRM best practices in enhancing firm performance. It was discovered that HRM best practices enhance firm performance. The study found that performance appraisal, internal communication, career planning, training and development, recruitment and selection, and SHRM alignment in the organization have positive relationship on firm performance. The results found in this analysis are consistent with the previous studies, such as performance appraisal, training, and recruitment (Youndt et al., 1996; Singh, 2003(a)\&(b); Wright et al., 2005; Cho et al., 2006; Khan, 2010; Quresh et al., 2010; Arumugam \& Mojtahedzadeh, 2011; Boohene \& Asuinura, 2011), career planning (Fey et al., 2000; Singh 2003(a)\&(b); Quresh et al., 2010; Nayyab et al., 2011), internal communication (Guest, 1997; Hoque, 1999; Singh, 2003(a)\&(b); Erdil \& Gunsel, 2007; Gurbuz \& Mert, 2011), and strategic HRM alignment in the organization (Paauwe \& Richardson, 1997; Abdullah et al., 2009; Gurbuz \& Mert, 2011; Ishak et al., 2011; Osman et al., 2011; Pham, 2011). This study concludes that HRM plays a crucial role in service companies (Schneider \& Bowen, 1993) and performance appraisal practices was high in practice in the insurance firms.

Performance appraisal practices are growing as a key role of managing individual performance, discussing critical success factors in the job, and provide the key inputs to decision on merit-based salary increases, training, and promotion (Boxall \& Purcell, 2003). Insurance firms stress the importance of effective performance appraisal management based on the belief that everything people do at work at any level contributes to achieving the overall purpose of the organization. It is therefore concerned with what employees do, how they behave, how they perform their work, and what they have achieved. The combined impact of performance appraisal practices will be expected to achieve more to improve firm performance.

The result of this study is consistent with Huselid et al.'s (1997) finding concludes that there is positive link between HRM effectiveness and firm performance. The practices of HRM undertaken in this study are concerned with how people are employed, managed, developed, rewarded, and taken care of as to achieve competitive advantage through the strategic deployment of a highly committed and capable workforce. This shows that organization is highly dependent on human resource to 
achieve high firm performance. There has been a debate by numerous academicians on the contribution of HRM practices in firm performance. Lau \& Ngo (2004) argues that a firm can achieve high performance through a universal set of HRM best practices. However, Schuler \& Jackson (1987); Schuler \& Walker (1990); Dyer \& Reeves (1995) view that HRM strategy would be more effective and efficient when appropriately integrated vertically between an organization's business strategy and its HRM policies and practices.

The implications of this study indicate that insurance firm must strategically manage its human resource practices to achieve maximum performance. Human Resource Personnel should focus on how to develop and sustain its human resource through effective HRM best practices to enhance current and future performance of the organization. The HRM system in Malaysia went through great transformations in the early 1990s and one of the main goals of HRM system is to ensure that HRM best practices are integrated with the strategy and the strategic needs of the firm in order to achieve sustainable competitive advantage. Conclusively, the contribution of this study is that effective HRM practices organises the overall organization-level HRM measures with the goal of gaining competitive advantage through human resources that will lead to high firm performance.

\section{LIMITATIONS AND FUTURE DIRECTION}

This research has several limitations. The construction of the research questionnaire did not consist of sufficient items to explore the relationships between HRM best practices and firm performance. Only eight out of a wide range of possible HRM best practices were selected in this study. Selection of HRM best practices items were based on the most popular HRM best practices quoted from previous studies. Therefore, the results of this study may be biased. This study only focused on the Malaysian insurance industry and the results may differ from other industries in Malaysia or other countries. This study may be taken up to cover a wider area such as insurance business unit branches and more respondents with cross cultural extensions. Future researchers may take up studies on HRM for these aspects.

\section{References}

Abdullah, Z., Ahsan, N., \& Alam, S.S. (2009). The effect of human resource management practices on business performance among private companies in Malaysia. International Journal of Business and Management, 4(6): 65-72.

Ahmad, S., \& Schroeder, R.G. (2003). The impact of human resource management practices on operational performance: Recognising country and industry differences. Journal of Operations Management, 21(1): 19-25.

Akhtar, S., Ding, D.Z., \& Ge, G.L. (2008). Strategic HRM practices and their impact on company performance in Chinese enterprises. Human Resource Management, 47(1): 15-32.

Armstrong, M. (2007). A handbook of human resource management practice (10th ed). London: Kogan Page.

Arthur, J.B. (1992). The link between business strategy and industrial relations systems in American steel mini-mills. 


\title{
ПРИМЕРИ НАЈБОЉЕ ПРАКСЕ УПРАВЉА ЉУДСКИМ \\ РЕСУРСИМА И УТИЦАЈ НА ПЕРФОРМАНСЕ КОМПАНИЈА: ПРИСТУП УНИВЕРЗАЛНЕ ПЕРСПЕКТИВЕ
}

\author{
Loo-See Beh, Leap-Han Loo
}

\begin{abstract}
Извод
Универзална перспектива менаџмента људским ресурсима подразумева да сет практичних алата може унапредити конкурентску предност и показатеље компаније. Ова студија се заснива на покушају истраживања односа између праксе управљања људским ресурсима и перформанси компаније. Како би се сакупили полазни подаци коришћен је упитник, док је испитивање вршено личним приступом. Популацију која је истраживана (312 испитаника) сачињавали су нижи, виши и високи менаџмент нивои из седам највећих осигуравајућих компанија из Кленг низије у Малезији. Истраживање је показало да је се најбоља пракса менаџмента људских ресурса састоји у унапређењу личних перформанси, унутрашњој комуникацији и планирању каријере запошљених.
\end{abstract}

Кључне речи: пракса управљања људским ресурсима, компаративна предност, перформансе компаније, осигуравајуће компаније, Малезија

Industrial and Labor Relations Review, The effect of human resources management 45(3): 488-506.

practices on corporate performance: a study

Arumugam, V.C., \& Mojtahedzadeh, R. (2011). The impact of human resource management practices on financial of graphic communication group limited. International Business Research, 4(1): 266performance of Malaysian industries. International Research Journal of Finance and Economics, 80: 49-54.

Bae, J., \& Lawler, J.J. (2000). Organizational and HRM strategies in Korea: Impact on firm performance in an emerging economy. Academy of Management Journal, 43(3): 502-517.

Bernardin, H.J., \& Russell, J.E.A. (1993). Human resource management: An experiential approach. Singapore: McGrawHill Inc.

Bjorkman, I., \& Fan, X.C. (2002). Human resource management and the performance of Western firms in China. International Journal of Human Resource Management, 13(6): 853-864.

Boohene, K., \& Asuinura, E.L. (2011). 272.

Boxall, P., \& Purcell, J. (2000). Strategic human resource management: Where have we come from and where should we be going? International Journal of Management Reviews, 2(2): 183-203.

Boxall, P., \& Purcell, J. (2003). Strategy and human resource management. New York: Palgrave Macmillan.

Champion, M.A. (1988). Interdisciplinary approaches to job design: A constructive replication with extensions. Journal of Applied Psychology, 73(3): 467-481.

Chang, P.L., \& Chen, W.L. (2002). The effect of human resource management practices on firm performance: Empirical evidence from high-tech firms in Taiwan. International Journal of Management, 19(4): 622-638. 
Chiu, R.K., Luk, V.W.M., \& Tang, T.L. (2002). Retaining and motivating employees: Compensation preferences in Hong Kong and China. Personnel Review, 31(4): 402-431.

Cho, S.H., Woods, R.H., Jang, S.C. \& Erdem, M. (2006). Measuring the impact of human resource management practices on hospitality firm's performances. Hospitality Management, 25: 262-277.

Collins, C.J., \& Clark, K.D. (2003). Strategic human resource practices, top management team social networks, and firm performance: The role of human resource practices in creating organizational competitive advantage. Academy of Management Journal, 46(6): 740-751.

Delaney, J., \& Huselid, M. (1996). The impact of HRM practices on perceptions of organizational performance. Academy of Management Journal, 39(4): 949-969.

Delery, J.E., \& Doty, D.H. (1996). Modes of theorizing in strategic HRM: Tests of universalistic, contingency, and configurational performance predictions. Academy of Management Journal, 39(4): 802-835.

Dyer, L.D., \& Reeves, T. (1995). Human resource strategies and firm performance: What do we know and where do we need to go? International Journal of Human Resource Management, 6(3): 656-670.

Erdil, O., \& Gunsel, A. (2007). Relationship between human resource management practices, business strategy fit and firm performance. Journal of Global Strategic Management, 1(1): 97-107.

Fey, C.F., Bjorkman, I., \& Pavlovskaya, A. (2000). The effect of human resource management practices on firm performance in Russia. International Journal of Human Resource Management, 11(1): 1-18.

Geringer, J.M., Frayne, C.A., \& Milliman,
J.F. (2002). In search of 'best practices' in international human resource management: Research design \& methodology. Human Resource Management, 41(1): 5-30.

Gooderham, P., Nordhaug, O., \& Ringdal, K. (2006). National embeddedness and calculative human resource management in US subsidiaries in Europe and Australia. Human Relations, 59(11): 1491-1513.

Guest, D.E. (1997). Human resource management: A review and research agenda. International Journal of Human Resource Management, 8(3): 263-276.

Guest, D.E., Michie, J., Conway, N., \& Sheehan, M. (2003). Human resource management and corporate performance in the UK. British Journal of Industrial Relations, 41(2): 291-314.

Gurbuz, S., \& Mert, I.S. (2011). Impact of the strategic human resource management on organizational performance: evidence from Turkey. The International Journal of Human Resource Management, 22(8): 1803-1822.

Guthrie, J. (2001). High-involvement work practices, turnover, and productivity: Evidence from New Zealand. Academy of Management Journal, 44(1): 180-190.

Harel, G.H., \& Tzafrir, S.S. (1999). The effect of human resource management practices on the perceptions of organizational and market performance of the firm. Human Resource Management, 38(3): 185-200.

Hiltrop, J.M. (2005). Creating HR capability in high performance organizations. Strategic Change, 14(3): 121131.

Hoque, K. (1999). Human resource management and performance in the UK hotel industry. British Journal of Industrial Relations, 37(3): 419-443.

Huselid, M.A. (1995). The impact of human resource management practices on 
turnover, productivity, and corporate Erlbaum Associates Publishers.

financial performance. Academy of Kundu, S.C. (2003). Workforce diversity Management Journal, 38(3): 635-672.

status: A study of employees' reactions.

Huselid, M.A., \& Becker, B.E. (1996).

Methodological issues in cross-sectional and panel estimates of the human resource-firm performance link. Industrial Relations, 35(3): 400-422.

Huselid, M.A., Jackson, S.E., \& Schuler, R.S. (1997). Technical and strategic human resource management effectiveness as determinants of firm performance. Academy of Management Journal, 40(1): 171-188.

Ishak, N.K., Abdullah, F.Z., \& Ramli, Z.A. (2011). The association between hard and soft human resource management orientations in the Malaysian hotel organizations. International Journal of Business and Social Science, 2(22): 213220.

Jackson, S.E., \& Schuler, R.S. (1995). Understanding human resource management in the context of organizations and their environments. Annual Review of Psychology, 46(1): 237-264.

Jackson, S.E., \& Schuler, R.S. (2000). Managing human resource. A partnership perspective. London: Southern-Western College Publishing.

Katuo, A., \& Budhwar, P. (2006). Human resource management systems and organizational performance: a test of a mediating model in the Greek manufacturing context. International Journal of Human Resource Management, 17(7): 1223-1253.

Khan, M.A. (2010). Effects of human resource management practices on organizational performance - an empirical study of oil and gas industry in Pakistan. European Journal of Economics, Finance and Administrative Sciences, 24: 157-175.

Kulik, C.T. (2004). Human resource for the non-hr manager. New Jersey: Lawrence 103(4): 215-226.

Kundu, S.C., \& Malhan, D. (2009). HRM practices in insurance companies: A study of Indian and multinational companies. Managing Global Transitions, 7(2): 191-215.

Lam, L.W., \& White, L.P. (1998). Human resource orientation and corporate performance. Human Resource Development Quarterly, 9(4): 351-364.

Lau, C.M., \& Ngo, H.Y. (2004). The HR system, organizational culture, and product innovation. International Business Review, 13(6): 685-703.

Liu, Y., Combs, J.G., Ketchen, D. J. J., \& Ireland, R.D. (2007). The value of human resource management for organizational performance. Business Horizons, 50: 503511.

MacDuffie, J.P. (1995). Human resource bundles and manufacturing performance: Organizational logic and flexible production systems in the world auto industry. Industrial and Labor Relations Review, 48(2): 197-221.

Marchington, M., \& Grugulis, I. (2000). "Best Practice" human resource management: Perfect opportunity or dangerous illusion? International Journal of Human Resource Management, 11(6): 11041124.

Mathis, R.L., \& Jackson, J.H. (2004). Human resource management. Singapore: Thomson Asia Pte. Ltd.

Miles, R.E., \& Snow, C.C. (1984). Designing strategic human resources systems. Organizational Dynamics, 13(1): 36-52.

Morgeson, F.P., \& Humphrey, S.E. (2006). The work design questionnaire (WDQ): Developing and validating a 
comprehensive measure for assessing job design and the nature of work. Journal of Applied Psychology, 91(6): 1321-1339.

Nayyab, H.H., Hamid, M., Naseer, F., \& Iqbal, M. (2011). The impact of HRM practices on the organizational performance. The study of banking sector in Okara, Punjab (Pakistan). Interdisciplinary Journal of Contemporary Research in Business, 3(3): 661-672.

Ngo, H.Y., Turban, D., Lui, C.M., \& Lui, S.Y. (1998). Human resource practices and firm performance of multinational corporations: Influences of country origin. International Journal of Human Resource Management, 9(4): 632-652.

Oladipo, J.A., \& Abdulkadir, D.S. (2011). Strategic human resource management and organizational performance in the Nigerian manufacturing sector: An empirical investigation. International Journal of Business and Management, 6(9): 46-56.

Osman, I., Ho, T.C.F., \& Galang, M.C. (2011). The relationship between human resource practices and firm performance: An empirical assessment of firms in Malaysia. Business Strategy Series, 12(1), 41-48.

Osterman, P. (1987). Choice of employment systems in internal labor markets. Industrial Relations, 26(1): 46-67.

Othman, A.E.A. (2009). Strategic HRM practices: Perspectives of Malaysian and Japanese owned companies in Malaysia. Global Business and Management Research, 1(1): 1-22.

Paauwe, J. (2004). HRM and performance achieving long term viability. Oxford: Oxford University Press.

Paauwe, J., \& Richardson, R. (1997). Introduction: Special issue on hrm and performance. The International Journal of Human Resource Management, 8(3): 257262.
Panayotopoulou, L., Bourantas, D., \& Papalexandris, N. (2003). Strategic human resource management and its effects on firm performance: An implementation of the competing values framework. International Journal of Human Resource Management, 14(4): 680-699.

Pham, L. (2011). Impact of applying human resource management practices on equitized state-owned enterprises' financial performance in Vietnam. Journal of International Business Research, 10(2): 7990.

Quresh, T.M., Akbar, A., Khan, M.A., Sheikh, R.A., \& Hijazi, T. (2010). Do human resource management practices have an impact on financial performance of banks? African Journal of Business Management, 4(7): 1281-1288.

Richard, O.C., \& Johnson, N.B. (2001). Strategic human resource management effectiveness and firm performance. International Journal of Human Resource Management, 12(2): 299-310.

Rose, R.C., \& Kumar, N. (2006). The influence of organisational and human resource management strategies on performance. Performance Improvement, 45(4): 18-24.

Schein, E.H. (1996). Culture: The missing concept in organizational studies. Administrative Science Quarterly, 41(2): 229-240.

Schneider, B. \& Bowen, D. (1993). The service organization: Human resource management is crucial. Organizational Dynamics, 21(4): 39-52.

Schuler, R.S., \& Jackson, S.E. (1987). Linking competitive strategies with human resource management practices. Academy of Management Executive, 1(3): 207-219.

Schuler, R.S., \& MacMillan, I. (1984). Gaining competitive advantage through 
human resource practices. Human Resource Management, 23(3): 241-256.

Schuler, R.S., \& Walker, J.W. (1990). Human resource strategy: Focusing on issues and actions. Organizational Dynamics, 19(1): 5-19.

Shipton, H., Fay, D., West, M., Patterson, M., \& Birdi, K. (2005). Managing people to promote innovation. Creativity and Innovation Management, 14(2): 118-128.

Singh, K. (2003a). Strategic HR orientation and firm performance in India. International Journal of Human Resource Management, 14(4): 530-543.

Singh, K. (2003b). The effect of human resources practices on firm performance in India. Human Resource Development International, 6(1): 101-116.

Sonnenfeld, J.A., \& Peiperl, M.A. (1988). Staffing policy as a strategic response: A typology of career systems. Academy of Management Review, 13(4): 588-600.

Terpstra, D.E., \& Rozell, E.J. (1993). The relationship of staffing practices to organizational level measures of performance. Personnel Psychology, 46(1): 27-48.

Tessema, M.T., \& Soeters, J,L. (2006). Challenges and prospects of HRM in developing countries: Testing the HRPperformance link in Eritrean civil service. International Journal of Human Resource Management, 17(1): 86-105.

Ulrich, D. (1991). Using human resources for competitive advantage. In R. Kilman, I. Kilman, \& Associates (Eds.). Making organizations competitive (pp.129-155). San Francisco: Jossey-Bass.

Ulrich, D. (1997). Measuring human resources: An overview of practice and a prescription for results. Human Resource Management, 36(3): 303-320.

Walters, M. (1995). The performance management book. London : Institute of Personnel and Development.

Wattanasupachoke, T. (2009). Strategic human resource management and organizational performance: A study of Thai Enterprises. Journal of Global Business Issues, 3(2): 139-148.

Wright, P.M., Gardner, T.M., Moynihan, L.M., \& Allen, M.R. (2005). The relationship between HR practices and firm performance: Examining causal order. Personnel Psychology, 58(2): 409-446.

Wright, P.M., \& McMahan, G.C. (1992). Theoretical perspectives for strategic human resource management. Journal of Management, 18(2): 295-320.

Youndt, M.A., Snell, S.A., Dean, J.W., \& Lepak, D.P. (1996). Human resource management, manufacturing strategy, and firm performance. Academy of Management Journal, 39(4): 836-866. 